\title{
Peran Modal Sosial Masyarakat dalam Pengelolaan Potensi Alam Sebagai Strategi Bertahan Hidup di Dusun Limang, Kecamatan Kelapa, Kabupaten Bangka Barat
}

\author{
Nopa Laura ${ }^{1}$, Rani Dian Sari ${ }^{2}$, Irfandi Setiawan ${ }^{3}$, Herdiyanti, M.Si $^{4}$ \\ Prodi Sosiologi, Fakultas Ilmu Sosial dan Ilmu Politik \\ Universitas Bangka Belitung
}

\begin{abstract}
This research focuses on one remote area or often referred to as hamlet. Limang Hamlet. This study uses descriptive qualitative research methods, with data collection techniques using pusposive sampling. The results of the research found in the field Social capital has become an important role in people's lives, especially rural communities. Therefore the community of Limang hamlet built the structure of the community's economy through recording and managing natural potential as a survival strategy in Limang Hamlet, Kelapa District, West Bangka Regency. This condition is supported by utilizing existing social capital in the Limang Hamlet community aimed at improving economic conditions to become more prosperous. The use of social capital carried out by the community of Limang Hamlet is done by bonding, bridging and linking. Social capital which is the reference for analyzing this research uses the theory of Woolcock. These three types of social capital are applied by the people of Limang Hamlet in developing their economy. The expansion of networks both internally and externally has been carried out effectively. Movements made made the people of Limang Hamlet known in many circles. Of course, with the use of natural potential owned by the community, helping people become more developed and productive.
\end{abstract}

Keywords: Social Capital, Survival, and Natural Potential

\section{ABSTRAK}

Peneilitian ini berfokus pada salah satu daerah terpencil yang sering disebut dengan nama Dusun Limang Penelitian ini menggunakan metode penelitian kualitatif deskriptif, dengan teknik pengumpulan data secara pusposive sampling. Adapun hasil penelitian yang ditemukan di lapangan Modal sosial menjadi peranan penting dalam kehidupan masyarakat khususnya masyarakat perdesaaan. Oleh karenanya masyarakat dusun Limang membangun struktur perekonomian masyarakat melalui pemanfatatan dan pengelolaan potensi alam sebagai strategi bertahan hidup di Dusun Limang, Kecamatan Kelapa, Kabupaten Bangka Barat. Kondisi ini didukung dengan memanfaatkan modal sosial yang ada pada masyarakat Dusun Limang bertujuan memperbaiki kondisi ekonomi menjadi lebih sejahtera. Pemanfaatan modal social yang dilakukan oleh masyarakat Dusun Limang dilakukan secara bonding, bridging dan linking. Modal sosial yang menjadi rujukan analisa penelitian ini menggunakan teori Woolcock. Ketiga tipe modal social ini diterapkan oleh masyarakat Dusun Limang dalam mengembangkan perekonomiannya. Perluasan jaringan baik secara internal maupun eksternal telah dilakukan secara efektif. Pergerakan yang dilakukan membuat masyarakat Dusun Limang dikenal di banyak kalangan. Tentunya dengan adanya pemanfaatan potensi alam yang dimiliki oleh masyarakat, membantu masyarakat menjadi lebih berkembang dan produktif.

Kata Kunci : Modal Sosial, Bertahan Hidup, dan Potensi Alam 


\section{PENDAHULUAN}

Bangka belitung merupakan salah satu provinsi yang memiliki sumber daya alam yang melimpah. Selain timah, potensi sumber daya laut, sungai, hutan dan sumber daya lainnya menjadi penunjang perekonomian masyarakat bangka belitung. Salah satu daerah yang memiliki sumber daya alam melimpah adalah Dusun Limang, Desa Pangkal Beras, Kecamatan Kelapa, Kabupaten Bangka Barat. Daerah ini, merupakan salah satu daerah pedalaman di Bangka Barat yang masih memiliki masalah kependudukan, mulai dari infrastruktur, pendidikan sampai dengan perekonomian. Dusun limang adalah dusun yang terletak cukup jauh jaraknya dari Desa Pangkal Beras. Akses yang mereka punya cukup sulit untuk melakukan aktivitas kehidupan seharihari. Penyebab salah satunya adalah infrastruktur yang mereka punya belum layak, sehingga menjadikan satu diantaranya pendidikan yang rendah.

Masalah pendidikan ditunjukkan dengan anak-anak yang putus sekolah, bahkan yang tidak lulus di tingkat pendidikan sekolah dasar. Bahkan sangat sulit ditemukan anakanak yang lulus pendidikan di jenjang pendidikan SMP dan SMA. Alasan masyarakat setempat, itu dikarenakan infrastruktur yang kurang layak, sehingga masih menjadi penghalang besar bagi anakanak mereka untuk sekolah. Mulai jauhnya jarak ke sekolah dari tempat tinggal mereka, jalan yang rusak, dan jembatan yang mengancam keselamatan anak-anak mereka.Selain itu, kondisi perekomonomian masyarakat setempat, juga menjadi persoalan bagi mereka untuk mengenyam pendidikan. Di Dusun Limang mayoritas masyarakat mata pencahariannya adalah nelayan, sementara kaum hawa berprofesi sebagai pembuat atap dari daun nipah. Usaha itu, digeluti kaum ibu-ibu Dusun setempat, dikarenakan letak Dusun Limau yang dikelilingi oleh sungai.

Sumber Daya Alam yang dimiliki oleh masyarakat beragam dan melimpah, mulai dari kepiting bakau, udang, ikan, dan lainlain. Namun, potensi alam yang dimiliki hanya dimanfaatkan untuk melangsungkan kehidupan masyarakat sehari-sehari, tidak hanya itu saja potensi alam yang dimiliki dijual degan harga murah demi bertahan hidup. Kondisi demikian terjadi karena masyarakat beralasan, sulit untuk melakukan pemasaran keluar dari Dusun Limang, karena keterbatasan kemampuan dan fasilitas yang ada. Banyak yang berdagang, tetapi dengan harga yang murah, hanya setengah harga dari desa atau daerah nelayan lainnya, atau sama sekali hanya dihabiskan untuk kebutuhan sehari-hari. Sebenarnya, daerah Dusun Limang merupakan salah satu asset kemajuan daerah Bangka Barat, jika SDA yang mereka punya dikembangkan sebagai tempat pembudidaya sektor perikanan. Oleh karena itu, penulis ingin mengkaji lebih dalam mengenai peran modal sosial masyarakat dalam pengelolaan potensi alam sebagai strategi bertahan hidup di Dusun Limang, KecamatanKelapa, Kabupaten Bangka.

\section{LANDASAN TEORI}

Penelitian ini mencoba melihat bagaimana peran modal sosial dalam suatu masyarakat dalam Pengelolaan Potensi Alam Sebagai Strategi Bertahan Hidup Di Dusun Limang, Kec. Kelapa Kab.Bangka Barat Untuk itu peneliti menggunakan teori modal sosial Woolcock. Modal sosial didefinisikan sebagai suatu unsur yang memiliki dua ciri yaitu aspek struktur sosial dan memfasilitasi tindakan individu dalam suatu struktur sosial masyarakat. Dalam pengertian ini, unsusr-unsur modal sosial berupa hubungan sosial, institusi sosial, serta nilai atau norma yang efektif dapat digunakan secara tepat dan melahirkan kontrak sosial, tanggung jawab sosial, kemandirian, dan peran serta. Modal sosial juga bagian-bagian dari organisasi sosial sperti kepercayaan, norma dan jaringan yang dapat meningkatkan efesiensi masyarakat dalam memfasilitasi tindakan-tindakan yang terkoordinasi.

Cox (1995) mendefinisikan, modal sosial sebagai suatu rangkaian proses hubungan antar manusia yang ditopang oleh jaringan, norma-norma, kepercayaan sosial 
yang memungkinkan efisien dan efektifnya koordinasi dan kerjasama untuk keuntungan dan kebijakan bersama. Kemudian dimensi modal sosial tumbuh di dalam suatu masyarakat yang di dalamnya berisi nilai dan norma serta pola-pola interaksi sosial dalam mengatur kehidupan keseharian anggotanya. Oleh karena itu menurut Hasbullah (2006), dimensi ini telaah dari modal sosial terletak pada bagaimana kemampuan masyarakat untuk bekerjasama membangun suatu jaringan guna mencapai tujuan bersama. Kerjasama tersebut diwarnai oleh suatu pola interrelasi yang timbal balik dan saling menguntungkan serta dibangun diats kepepercayaan yang ditopang oleh norma-norma dan nilai-nilai sosial yang positif dan kuat. Kekutan tersebut akan maksimal jika didukung oleh semangat proaktif membuat jalinan hubungan diatas prinsip-prinsip sikap yang partisifatif, saling memberi dan menerima, saling percaya dan diperkuat oleh nilai-nilai dan norma-norma yang mendukungnya.

Untuk itu, adanya perhatian terhdap modal sosial pada umumnya tertarik untuk dikaji kerekatan hubungan sosial dimana masyarakat terlibat didalamnya, terutama kaitannya dengan pola-pola interaksi sosial atau hubungan sosial antar anggota masyarakat atau kelompok dalam suatu kegiatan sosial. Bagaiamana dalam ini menarik untuk dikaji karena keanggotaan dan aktivitas mereka dalam suatu asosiasi sosial merupakan hal yang menarik. Oleh sebab itu Wolcock (2004) menyebutkan tiga tipe modal sosial :

1. Social bounding (perekat sosial) nilai, kultur, persepsi, dan tradisi atau adat- istiadat. Social bounding adalah, tipe modal sosial dengan karakteristik adanya ikatan yang kuat (adanya perekat sosial ) dalam suatu sistem masyarakat. Misalnya rasa kekerabatan yaitu menyebabkan adanya rasa empati/ kebersamaan. Bisa nuga mewujudkan rasa simapti, rasa berkewajiban, rasa percaya, resiprositas, pengakuan timbal balik kebudayaan yang mereka percaya.
2. Social bridging (jembatan sosial), bisa berupa institusi maupun mekanisme. sosial bridging merupakan suatu ikatan sosial yang timbul sebagai reaksi atas berbagai macam karakteristik kelompoknya. Ia bisa muncul karena adanya berbagai macam kelemahan disekitarnya, sehingga mereka memutuskan untuk membangun kekuatan kelemahan. Social bridging bisa juga dilihat dengan adanya ketrlibatan umum sebagai warga negara, asosiasi, dan jaringan. Tujuannya adalah mengembangkan potensi yang ada dalam masyarakat agar masyarakat mampu menggali dan memaksimalkan kekuatan yang memiliki baik SDM (Sumber Daya Manusia) dan SDA (Sumber Daya Alam) dapat dicapai. Kapasitas modal sosial termanifestasikan dalam ketiga bentuk modal sosial tersebut (nilai, institusi, dan mekanisme) yang dapat memfasilitasi dan menjadi arena dalam hubungan antarwarga, antarkelompok agar mampu mengembangkan modal sosial untuk membangun integrasi sosilal.

3. Social linking (hubungan/jaringan sosial) merupakan hubungan sosial yang dikarakteristikan dengan adanya hubungan diantara beberapa level dari kekuatan sosial maupun status sosial yang ada dalam masyarakat. Pada dasarnya ketiga tipe modal sosial ini dapat bekerja tergantung dari keadaannya. Ia dapat bekerja dalam kelemahan maupun kelebihan dalam suatu masyarakat. Ia dapat digunakan dan dijadikan pendukung sekaligus penghambatahn dalam ikatan sosial tergantung bagaimana individu dan masyarakat.

Untuk itu berdasarkan penejelasan dari tipe modal sosial yang dikeluarkan oleh Wolcock (2006) maka aka ada kaitannya dengan pemasalahan yang akan diteliti khususnya dalam masyarakat Dusun Limang. Dimana adanya relevansi ke tiga 
tipe diatas yaitu social bounding,social bridging, dan social linking dengan peran modal sosial dalam pengelolaan potensi alam sebagai strategi bertahan hidup di Dusun Limang yang diterapkan oleh masyarakat setempat yaitu, adanya solidaritas, kepercayaan, kerjasama, kesadaran yang mendukung akan pentingnya dalam meningkatkan kondisi eknomi da serta adanya institusi atau pemerintah yang mendukung akan mekanisme modal sosial yang mereka terapkan.

Penelitian ini secara khusus mengkaji tentang peran modal sosial masyarakat dalam pengelolaan alam sebagai strategi bertahan hidup di Dusun Limau, Kec. Kelapa Kab. Bangka Barat. Penelitian ini sebelumnya belum pernah dilakukan, kecuali pada penelitian tentang modal sosial pada objek penelitian yang berbeda. Untuk itu peneliti menggunakan penelitian terdahulu yang menjadi acuan dalam penelitian ini, diantaranya jurnal yang ditulis oleh Ayu Kusumawati (2017) mengangkat judul "Modal Sosial dan Mekanisme Adaptasi Masyarakat Pedesaan dalam Pengelolaan dan Pembangunan Infrastruktur". Penelitian ini menggunakan kualitatif deskriptif. Penelitian ini melihat modal sosial terikat (bonding) dapat menjadi sebuah kekuatan dalam menghasilkan kapasitas adaptasi masyarakat pedesaan dalam pengelolaan dan pembangunan infrastruktur.

Hasil penelitian Ayu Kusumawati tentang modal sosial dan mekanisme adaptasi masyarakat pedesaan dalam pengelolaan dan pembangunan infrastruktur adalah pembangunan infrastruktur (air, listrik, dan jalan) masyarakat mengembangkan kepercayaan, interaksi yang kuat antar sesama anggota, norma/aturan yang menunjukkan tipe modal sosial bonding. Modal sosial yang terikat ini menghasilkan kapasitas adaptasi, antara lain berupa: kerja sama, partisipasi semua elemen masyarakat, pemanfaatan teknologi yang sesuai kebutuhan masyarakat, prinsip saling menjaga, dan kemampuan memobilisasi sumber daya kolektif dalam anggota kelompok. Bentuk-bentuk kapasitas adaptasi yang dikembangkan adalah sebuah daya lenting dan fleksibilitas untuk menjaga stabilitas pembangunan dan pengelolaan infratsruktur perdesaan.

Penelitian berikutnya adalah penelitian yang dilakukan oleh Rezi Prayoga (2017) mengangkat judul "Ekspansi Desa dan Implikasinya Terhadap Kehidupan Sosial Budaya Masyarakat". Penelitian ini menggunakan metode kualitatif dengan pendekatan deskriptif. Penelitian ini membahas tentang pemekaran desa dan implikasinya terhadap hubungan-hubungan individu dalam masyarakat. hadirnya modal sosial di dalam masyarakat menjembantani individu dan kolektif, dimana modal sosial menjadi aset terpenting bagi individu yang dibangun dari sumber-sumber struktural sosial. Hasil penelitian Rezi menunjukkan bahwa pemekaran desa yang terjadi pada masyarakat desa "Kundi Bersatu" tidak menimbulkan dampak yang sangat signifikan terhadap kehidupan sosio-kultural masyarakat.

Berdasarkan pengamatan dari kedua penelitian terdahulu, maka terdapat dua hal yang dapat dilihat, yakni persamaan dan perbedaan. Persamaan yang dapat dilihat dari kedua penelitian sebelumnya baik tinjauan yang pertama maupun kedua, yakni sama-sama dilakukan penelitian tentang peran modal sosial pada masyarakat, kemudian membahas tentang potensi yang sumber daya alam maupun sumber daya manusia yang ada didaerah masyarakat yang menjadi objek penelitian. Sedangkan perbedaan yang dapat dilihat dari penelitian sebelumnya adalah dimana penelitian yang dilakukan oleh Ayu Kusumawati memfokuskan pada adaptasi masyarakat terhadap pembangunan. Sedangkan penelitian yang dilakukan oleh Rezi Prayoga lebih berfokus pada struktur sosial dan jaringan dalam kehidupan masyarakat "Kundi Bersatu". Sedangkan pada penelitian ini, peneliti lebih memfokuskan pada peran modal sosial dalam mengelola sumber daya alam yang merupakan salah satu strategi untuk bertahan hidup. 


\section{III.METODE PENELITIAN}

Penelitian ini menggunakan metode kualitatif dengan pendekatan deskriptif. Penelitian ini bertujuan untuk menggambarkan dan meringkaskan berbagai kondisi, situasi atau fenomena realitas sosial yang ada dimasyarakat. Penelitian ini berusaha menarik realitas sosial kepermukaan sebagai suatu ciri, karakter, sifat, model, tanda atau gamabaran tetang kondisi, situasi ataupun fenomena tertentu.

Dalam penelitian ini, teknik pengumpulan data dilakukan dengan wawancara, observasi, serta melalui studi kepustakaan seperti buku-buku, jurnal, skripsi dan informasi yang diperoleh dari sumber internet yang berkaitan dengan fokus penelitian. Penentuan informan dilakukan dengan cara menggunakan teknik purposive sampling yang terdiri dari masyarakat, tokoh masyarakat, kepala dusun, kepala desa dan pemerintah Bangka Barat.

\section{HASIL PENELITIAN DAN PEMBAHASAN}

Dusun Limang Desa Pangkal Beras Kecamatan Kelapa Kabupaten Bangka Barat menjadi salah satu daerah yang menjadi ranah perhatian masyarakat Bangka Barat khususnya. Dusun limau merupakan salah satu daerah terpencil yang sulit untuk di di capai karena minimnya akses untuk menempuh jarak yang cukup jauh. Berbagai permasalah dari setiap aspek dalam kehidupan masyarakat menjadi persoalan penting didaerah tersebut, mulai dari pendidikan, sosial, ekonomi, lingkungan dan lain sebagainya. Hal inilah seringkali berdampak terhadap pertumbuhan dan perkembangan suatu daerah. Oleh sebab itu, ditengah banyak persoalan dan keterbatasan yang dirasakan masyarakat Dusun Limang, ternyata banyak halnya kekayaan tersembunyi yang dimiliki daerah tersebut salah satunya Sumber Daya Alam (SDA) yang berlimpah. Mulai dari madu, kepiting bakau, udang, daun nipah, sawit timah dan lain sebagainya menjadi kekuatan hidup masyarakat setempat. Saat ini dusun limau sangat dikenal sebagai daerah penghasil madu pelakat yang dinamakan sebagai madu utama. Madu tersebut telah dipasarakan kebeberapa daerah, dan diikut sertakan dibebagai pameran bergengsi di Indonesia, seperti pameran di Bandung, Jakarta, Semarang dan lain sebagainya.

\section{A. Demografi Masyarakat Dusun Limau}

Dusun Limang adalah salah satu dusun yang tereletak di sudut barat pulau Bangka yang merupakan bagian dari salah satu wilayah kecamatan Kelapa. Luas daerah Dusun Limang $150 \mathrm{Ha}$ sedangkan luas wilayah yang diajukan ke pemerintah setempat seluas 3,5 Ha. Kemudian jumlah penduduk Dusun Limau berjumlah 175 jiwa dengan beranekaragam pekerjaan yang dilakukan mulai dari nelayan penagkap udang satang, tengkulak udang, ikan dan kepiting, pembuat atap nipah, petani sahang, penyadap getah karet, petani sawit, dan peternak madu. Dan berdasarakan pekerjaan penggolongan pembagian kerja sangat diperhatikan dimana perempuan hanya sebatas bekerja sebagai pembuat atap daun nipah dan penyadap karet, selebihnya. Lakilaki sebagai pemeran dalam berbagai jenis pekerjaan. Dan banyak anak yang sedang menempuh pedidikan yaitu 17 orang.

\section{B. Keadaan Perekonomian dan Potensi Alam yang Dimiliki Masyarakat Dusun Limang}

Dusun Limang adalah salah satu dusun di Bangka barat yang mempunyai potensi Sumber Daya Sumber Daya Alam (SDA) yang melimpah yaitu lada, sawit, karet, nipah, madu, udang, ikan, dan kepiting bakau. Oleh sebab itu pekerjaan masyarakat di Dusun Limang juga beraneka ragam mulai dari petani karet, petani lada, petani sawit, nelayan, pembuat atap daun nipah dan pembudidaya madu dan lain sebagainya. Dengan demikian pekerjaan masyarakat didaerah ini sesuai dengan musim apa. Misanyal pada saat musim udang atau keeping bakau banyak masyarakat yang mata pecahariannya sebagai nelayan begitu pun sebaliknya pada saat cuaca kurang baik untuk melakukan ruitinitas nelayan 
masyarakat beralih ke petani penyadap getah karet, petani sawit, lada dan sebagainya. Berbeda halnya dengan perempuan yaitu bekerja membuat atap dari daun nipah dimana bahan bakunya di cari oleh para laki-laki pada saat nelayan.

Pada awal mulanya perekonomian masyarakat Dusun Limang sangatlah minim dimana kehidupan masyarakat sangatlah tergantung dengan hasil alam. Misalnya masyarakat hanya makan ikan apabila suami atau orang tuanya menjadi nelayan. Perempuan hanya bekerja sebagai pembuat atap nipah dengan harga satu keeping dua ribu rupiah. Hasil nelayan yang diperoleh acap kali hanya untuk makan sehari-hari. Jadi, tak jarang jika nelayan mempunyai hasil penangkapan cukup banyak bisa diujual tetapi dengan harga yang sangat murah, biasanya setengah harga dari daerah luar lainnya. Dari beberapa permsaalahan itu munculnya salah satu masyarakat yang mencoba melahirkan potensi baru yaitu Kepala Dusun Limang Bapak Kus , dimana beliau melalukan percobaan untuk membudidaya madu kelulut. Hal ini dimulai dengan adanya kerja sama dengan pihak swasta dari kampung seberang. Setelah percobaan dilakukan banyak masyarakat yang tertarik untuk melalukan hal yang sama ingin melaukan budidaya madu.

Inilah salah satu cir khas masyarakat setempata dimana pekerjaan yang mereka lakukan yaitu sistem tematik, pekejaan sering kali dilakukan dengan satu tema yang sama. Oleh sebab itu, beberapa bulan setelah percobaan tenyata madu yang dihasilkann cukup banyak yaitu hampir setiap kepala keluarga mempunyai madu, sehingga ada potensi untuk melakukan dipasarkan keluar daerah. Dengann demikian, ada inisisatif dari kepala dusn dan masyarakat setempat untuk mengajukan bantuan ke pihak pemerintah Kabupaten, yaitu Bangka Barat agar mendapatkan bantuan dalam proses pengolahan, pengemasan, hingga pemasaran. Hal ini juga bertujuan untuk memperkenalkan potensi Sumber Daya Alam yang dimiliki masyarakat setempat di tengah-tengah banyaknya permasalahan dalam setiap aspek kehidupan.
Setelah proses tersebut dilakukan, ternyata langsung mendapatkan respon positif dari pemerintah kabupaten dan permerintah langsung melakuan survei lapangan untuk melihat apakah baik untuk dilakukan pengembangan Usaha Kecil Menengah (UKM) masyarakat setempat. Kemudian setelah dilakukan proses tersebut masyarakat lansung mendapatkan bantuan seperti alat-alat pemuatan sarang, botol dan label pengemasan. Hal ini tenyatanya sangat mendorong perekonomian masyarakat setempat yaitu dengan cepatnya dikenal oleh masyarakat sekitar bahwa Dusun Limang mempunyai potensi madu dengan kualitas yang sangat baik. Dalam pelaksanaan program tersebut masyakat Dusun Limang membentuk grup yang beranggotakan 25 orang agar memudakan dalam pelaksanaan budidaya madu serta up date dalam mendapatkan informasi baik informasi pengolahan maupun pemasaran.

Oleh sebab itu, perkembangan perekonomian masyarakat cukup naik dengan signifikan, hal ini disebabkan oleh banyaknya masyarakat atau pemerintah yang berdatangan untuk mencari madu kelulut yang dinamakan madu kelulut trigona sehingga masyarakat memanfaatkan untuk berjualan kepiting bakau, udang satang atau daun nipah dan lain sebagainya. Dari hal inilah munculnya banyak relasi yang terbentuk dan hadir juga dimasyarakat tengkulak atau agen penampung hasil nelayan sehingga masyarakat mempunyai wadah untuk memasarkan hasil tangkapan mereka. Kembali lagi kepada mad kelulut trogina yang dihasilkan masyarakat setempat ternyata sudah dipasarakan keberbagai pameran nasional di luar Bangka Belitung seperti Jakarta, Bandung, Semarang dan pameran ASEAN GAME di Palembang. Dan langsung disampaikan oleh bapak Kus bahwa kemajuan yang mereka harapkan mengenai Dusun Limang sudah mulai terlihat, ini berkat kerjasama semau kalangan baik pemerintah dan masyarakat sekitar sehingga sangat cepat dikenal oleh masyarakat luas baik dalam daerah maupun luar daerah. Produk madu unggulan yang dimiliki masyarakat dusun limau 
diantaranya: madu kelulut trigona, madu lubang, madu pelaben tau madu biasa, madu pahit dan polen.

Tetapi dalam pelaksanaan juga ada beberapa permasalahan yang dihadapi oleh masyarakat setempat dikarenakan di saat hasil panen menumpuk masyakat terkadang kesulitan untuk melakukan pengambilan hasil panen dikarenakan keterbatasan tenaga yang dimiliki oleh amsyarakat setempat, serta sulitnya menyeimbangi dengan permintaan pasar. Itu lah yang disampaikan oleh msyarakat setempat dimana belum ditemukan jalan keluar dalam permaslahan ini untuk tetap menstabilkan ekonomi masyarakat setempat dan banyak nya tawarann adri beberapa desa yang ingin bergabung dan bekerja sama, tetepai dengan adanya permsalahan tersebut masyarakat Dusun Limang belum dapat mengiyakan kerjasama tersebut.

\section{Peran Modal Sosial Masyarakat dalam Pengelolaan Potensi Alam Sebagai Strategi BertahanHidup di Dusun Limau, Kec. Kelapa Kab.Bangka Barat}

Modal sosial menyatakan bahwa sesuatu yang nyata dalam kehidupan sehari-hari dalam kehidupan sehari-hari masyarakat seperti simpati, hubungan sosial dan lain lain. Kegiatan atau kebiasaan masyarakat tidak telepas dari berbagai modal sosial yang diterapkan. Salah satunya dalam Pengelolaan Potensi Alam Sebagai Strategi Bertahan Hidup Di Dusun Limang, Kec. Kelapa Kab.Bangka Barat. Dimana adanya relevansi dengan modal sosial yang dijelaskan oleh Wolcock yang membagi modal sosial dalam 3 (tiga) tipe:

1. Social bounding (perekat sosial) nilai, kultur, persepsi, dan tradisi atau adat- istiadat. Social bounding adalah, tipe modal sosial dengan karakteristik adanya ikatan yang kuat (adanya perekat sosial) dalam suatu sistem masyarakat. Dalam social bounding adanya rasa empati yang yang dirasakan masyarakat sekitar, kemudian adanya kepercayaan yaitu sikap saling mempercayai dimasyarakat Dusun Limang dalam pengelelolaan seperti madu yang dihasilkan bersama diberikan kepercayaan pada salah satu masyarakat untuk mengelola madu tersebut.

2. Social bridging (jembatan sosial), bisa berupa institusi maupun mekanisme. sosial bridging merupakan suatu ikatan sosial yang timbul sebagai reaksi atas berbagai macam karakteristik kelompoknya. Ia bisa muncul karena adanya berbagai macam kelemahan disekitarnya, sehingga mereka memutuskan untuk membangun kekuatan kelemahan. Institusi adalah suatu lembaga yang hadir dalam ranah masyarakat yang berperan sebagai fasilitas dalam mengatasi permasalahan dalam mayarakat seperti pemerintah Kabupaten Bangka Barat yang memfasilitasi masyarakat Dusun Limang untuk meningkatkan hasil budidaya madu mulai dari pengelolaan, pengemasan sampai pemasaran. Pemasaran madu mengalami pengembangan hal ini berlangsung karena adanya dukungan Pemerintah Kabupaten Bangka.

3. Social linking (hubungan/jaringan sosial) merupakan hubungan sosial yang dikarakteristikan dengan adanya hubungan diantara beberapa level dari kekuatan sosial maupun status sosial yang ada dalam masyarakat. Social linking merupakan modal sosial yang bergerak pada tataran yang lebih luas, karena mereka membedakan status sosialnya. Social linking biasanya memberikan akses kepada organisasi atau sistem yang akan membantu masyarakat memperoleh sumberdaya untuk mendapatkan perubahan. Ikatan ini biasanya dihubungkan dengan organisasi seperti beberapa pihak swasta sebagai sponsor, mendapatakan 


\begin{tabular}{|c|c|c|c|}
\hline & \multirow[b]{2}{*}{ Persepsi } & \multirow[b]{2}{*}{$\begin{array}{l}\text { Adanya tanggapan atau } \\
\text { respon yang diraskan } \\
\text { masyarakat dari berbagai } \\
\text { kelangan mengenai } \\
\text { potensi yang dimiliki } \\
\text { mereka baikdari } \\
\text { pemerintah, masyarakat } \\
\text { dalam daerah maupun luar } \\
\text { daerah. }\end{array}$} \\
\hline $\begin{array}{l}\text { pengahargaan dari pemerintah } \\
\text { Provinsi Kepulauan Bangka Belitung } \\
\text { sebagai juara III UKM berprestasi } \\
\text { Provinsi Kepulauan Bangka Belitung } \\
\text { tahun } 2018 \text {. Serta kerjasama dengan } \\
\text { beberapa jaringan pemasaran luar } \\
\text { daerah baik pemerintah ataupun }\end{array}$ & & & \\
\hline $\begin{array}{l}\text { sampai tingkat Internasional hal ini } \\
\text { dibuktikan dengan adanya pegelaran } \\
\text { Asian Games } 2018 \text { di Indonesia. }\end{array}$ & \multirow[t]{2}{*}{ Social Bridging } & Institusi & $\begin{array}{l}\text { Pemerintah dusun limang } \\
\text { beserta pihakswatalocal, } \\
\text { nasional maupun } \\
\text { internasional }\end{array}$ \\
\hline $\begin{array}{l}\text { Pada } \text { kesempatan } \\
\text { Pemerintah } \\
\text { Kabupaten telah } \\
\text { mensuplay hasil produk masyarakat } \\
\text { Dusun Limang seperti madu dan }\end{array}$ & & Mekanis & $\begin{array}{l}\text { Pemeberian bantuan } \\
\text { berupa fasililitas } \\
\text { pembuatan sarang, alat dan } \\
\text { label pengemasan, serta } \\
\text { berupa modal lainnya. }\end{array}$ \\
\hline $\begin{array}{l}\text { lainnya untuk dipasarkan pada acara } \\
\text { tersebut. }\end{array}$ & \multirow[t]{2}{*}{ Social Linking } & $\begin{array}{l}\text { Hubunga } \\
\mathrm{n} / \text { jaringa }\end{array}$ & \multirow{2}{*}{$\begin{array}{l}\text { Pemerintah Provinsi, toko } \\
\text { oleh-oleh pameran luar } \\
\text { daerah baik yang } \\
\text { diselenggarakan oleh } \\
\text { pihak swasta maupun } \\
\text { pemerintah luar daerah, } \\
\text { tingkat Internasional. } \\
\end{array}$} \\
\hline $\begin{array}{lcc} & \text { Tabel a. } \\
\text { Pemetaan Konsep Modal Sosial yang } & \text { yasyarat } \\
\text { Diterapakan } & \text { Masyarakat dalam } \\
\text { Pengelolaan } & \text { Potensi Alam Sebagai }\end{array}$ & & nsocial & \\
\hline Strategi Bertahan Hidup di Dusun & $\begin{array}{l}\text { Sumber } \\
2018 .\end{array}$ & ahan Dc & Oleh Peneliti Tahun \\
\hline
\end{tabular}

\begin{tabular}{|c|c|c|}
\hline Dimensi Modal Sosial & Indikator & $\begin{array}{l}\text { Penerapan masyarakat } \\
\text { dalam Pengelolaan Potensi } \\
\text { Alam Sebagai Strategi } \\
\text { Bertahan Hidup Di } \\
\text { DusunLimau, Kec. Kelapa } \\
\text { Kab. Bangka Barat }\end{array}$ \\
\hline \multirow[t]{4}{*}{ Social Bounding } & Nilai & $\begin{array}{l}\text { Kepercayaan sesame } \\
\text { masyarakat dalam } \\
\text { pengeloaan potensi yang } \\
\text { dihasilkan masyarakat } \\
\text { setempat terhadap satu } \\
\text { orang. }\end{array}$ \\
\hline & $\begin{array}{l}\text { Solidarit } \\
\text { as }\end{array}$ & $\begin{array}{l}\text {-Kerjasama antar sesama } \\
\text { yang kuat } \\
\text {-Pengeloaan hasil panen } \\
\text { secarabersama } \\
\text {-Saling membantu } \\
\text { kesulitan yang dihadapi } \\
\text { dalam meningkat kan } \\
\text { ekonomi bersama }\end{array}$ \\
\hline & Empati & $\begin{array}{l}\text { Adanya rasa peduli satu } \\
\text { sama lain melalui kerja } \\
\text { samasaling menguatkan } \\
\text { satu denga yang lainnya }\end{array}$ \\
\hline & Kultur & $\begin{array}{l}\text { Estetika tradisi yang } \\
\text { dibentuk melalui adanya } \\
\text { rasa milikbersamatehadap } \\
\text { potensi yang ada. Dan } \\
\text { penguatan sistem kerja } \\
\text { tematik masyarakat } \\
\text { Dususn limang }\end{array}$ \\
\hline
\end{tabular}

\section{KESIMPULAN}

Modal sosial menjadi peranan penting dalam kehidupan masyarakat khususnya masyarakat perdesaaan. Dalam hal ini masyarakat perdesaan khususnya masyarakat Dusun Limang memanfaatkan modal sebagai aset dalam melangsungkan penghidupan untuk bertahan hidup. Oleh karenanya masyarakat dusun Limang membangun struktur perekonomian masyarakat melalui pemanfatatan dan pengelolaan potensi alam sebagai strategi bertahan hidup di Dusun Limang, Kecamatan Kelapa, Kabupaten Bangka Barat. Kondisi ini didukung dengan memanfaatkan modal sosial yang ada pada masyarakat Dusun Limang bertujuan memperbaiki kondisi ekonomi menjadi lebih sejahtera.

Lebih lanjut mekanisme peran modal sosial yang diterapkan masyarakat Dusun Limang dalam kondisi tersebut sama halnya dengan yang di kemukakan oleh Woolcock yaitu modal sosial dibagi ke dalam tiga tipe yakni modal sosial yang mengikat (Bonding Social Capital) merupakan jenis modal sosial lebih banyak bekerja secara internal 
dan solidaritas yang dibangun oleh masyarakat Dusun Limang diantara masyarakat internal. Hubungan sosial yang dibangun tentu memiliki alasan tersendiri dikarenakan menimbulkan kohesi sosial yang lebih bersifat mikro dan komunal karena itu hubungan yang terjalin di dalamnya lebih bersifat eksklusif untuk saling terbuka satu sama lain antar masyarakat Dusun Limang. Selanjutnya, Bridging Social Capital nya sebagai diterapkan oleh masyarakat Dusun Limang dengan tujuan mengembangkan kerjasama dan memudahkan mekanisme kerja tersebut baik secara internal maupun eksternal di luar masyarakat Dusun Limang. Bentuk modal social bridging social capital bersifat inklusif dengan lebih banyak menjalin jaringan dengan potensi eksternal yang melekat padanya hal ini memudahkan masyarakat untuk mendapatkan akses yang lebih luas terkait hubungan sosial atau jaringan sosial yang dimiliki. Terakhir masyarakat juga memanfaatkan modal sosial yang menghubungkan (Linking Social Capital) merupakan modal sosial yang bergerak pada tataran lebih luas, karena mereka tidak membedakan kelas dan status sosialnya.Hal ini dibuktikan dengan adanya produk yang dihasilkan oleh masyarakat Dusun Limang hingga dikenal oleh Negara luar seperti Malaysia, Thailand dan sebagainya pada acara Asian Games 2018.

\section{DAFTAR PUSTAKA}

[1] Cox, Eva. (1995). A Trully Civil Society. ABC Book, Sydney.

[2] Kusumastuti, Ayu. (2015). Modal Sosial dan Mekanisme Adaptasi Masyarakat Pedesaan dalam Pengelolaan dan Pembangunan Insfrastruktur. Mayarakat: Jurnal Sosiologi, 20(1):8197.

[3] Prayoga, R. 2017. Ekspansi Desa dan Implikasinya Terhadap Kehidupan Sosial Budaya Masyarakat: (Studi Pada Masyarakat 'Kundi Bersatu' Kecamatan Simpang Teritip Kabupaten Bangka). Society. 5, 2 (Des 2017), 84-99. DOI:https://doi.org/10.33019/society.v5i 2.56 .

[4] Sairi. (2006). Sosial Kapita: Menuju Keunggulan Budaya Manusia Indonesia. MR-United Press, Jakarta.

[5] Woolcock, Michael. (2004). Using Social Capital: Theory and Practice of Economic Development Princeton, NJ: Princeton University Press (Forthcoming).

[6] Woolcock, Michael and Deepa Narayan. (2006). Social Capital: Implication for Development Theory, Research, and Policy Revisted. In Bebbington, Anthony; M. Woolcock; Scott E.G.; and Elizabeth A. Olson: The Search for Empowerment: Social Capital as Idea and Practice at the World Bank. Kumarian Press, Inc. USA. 